\title{
The Enforcement of Foreign Arbitral Awards in Kuwait
}

\begin{abstract}
SAAD BADAH
Abstract. This article is an analysis of the enforcement of foreign arbitral awards in Kuwait, an Islamic nation governed by Sharia law. The need for this analysis stems from the potential conflict between the Convention on the Recognition and Enforcement of Foreign Arbitral Awards (1958) (the 'New York Convention') (which came into effect in Kuwait on 27 July 1978) and Sharia law and the need to merge the two into a cohesive legal system. The Gulf Cooperation Council (GCC) has a representative office in Kuwait that facilitates the applicable provisions contained therein.
\end{abstract}

Keywords: The Enforcement of Foreign Arbitral Awards

\section{INTRODUCTION}

Arbitration, under international law, is referred to as a formal dispute settlement mechanism (Ragib 1993: 131-172), similar to a common judicial procedure (Rothwell-KayeAkhatkavari-Davis 2011). Arbitration is a binding determination of a dispute by a third party who is sufficiently competent and knowledgeable to resolve a dispute in accordance with a set of legal principles (Rothwell-Kaye-Akhatkavari-Davis 2011: 673). Flexibility is offered to the disputing parties, with an arbitration tribunal being set up, both on an ad hoc or permanent basis, such as the Permanent Court of Arbitration. ${ }^{1}$

Arbitral awards, according to Article II of the Convention on the Recognition and Enforcement of Foreign Arbitral Awards (the 'New York Convention'), are defined as including 'not only awards made by the arbitrators appointed for each case but also those made by permanent arbitral bodies to which the parties have submitted'. ${ }^{2}$ This definition encompasses all kinds of arbitral awards to which the parties signatory to the Convention are party. According to the Convention, an arbitral award includes the 'agreement in writing' ${ }^{3}$ that is an arbitration agreement signed by the parties or an arbitration clause contained in an exchange of letters (Nacimiento 1966).

Article I(2) of the New York Convention has sought to ${ }^{4}$ define an arbitral award to mean that it will not be limited to awards that are made by the arbitrators appointed in each case but shall also include those that are made by permanent arbitral bodies to which the parties have submitted. ${ }^{5}$

The Judicial Arbitration Law No. 11 of 1995, for its part, does not provide a precise definition of foreign arbitration awards. It does, however, set out the procedure whereby a

11907 Convention for the Pacific Settlement of International Disputes (Hague I) [1997] ATS 6.

2 Article II of the New York Convention.

3 Article II(2) of the New York Convention.

${ }^{4}$ Article I(2) of the New York Convention.

${ }^{5}$ Article I(2) of the New York Convention.

Saad Badah, Doctoral candidate, Faculty of Law, Brunel University, UK. E-mail: sa3d51@hotmail.com (Received: 10.04.2014; revision received: 11.06.2014; accepted: 12.06.2014) 
panel of arbitrators can be formed in the Court of Appeal comprised of at least three judicial officers and two arbitrators to be chosen in each dispute for each party. ${ }^{6}$

Kuwait currently follows the procedures of the New York Convention, under the principle of reciprocity with public policy, as the main ground disqualifying enforcement of foreign arbitral awards in Kuwait. This is outlined in Kuwait's Code of Civil and Commercial Procedure. Additionally, legislation and practices that guide the enforcement and recognition of foreign arbitral awards include the UNCITRAL Model Law and domestic laws, as well as the various reservation clauses and reciprocity aspects. This article seeks to explore the concept of arbitration law and practice and arbitral awards in the context of Sharia law, and current arbitration laws in Kuwait as well as demonstrating how foreign arbitral awards are enforced in Kuwait and the grounds of non-enforcement of foreign arbitral awards, which include procedural and substantive technicalities arising from nonadherence to the law, arbitrator competency, legality of arbitral awards, and other provisions in the Code of Civil and Commercial Procedure.

\section{ARBITRATION IN SHARIA-BASED COUNTRIES}

The concept of arbitration is discussed in the Koran and therefore was deep-rooted within the Arab countries long before integration with Western countries. Arbitration is part of Islamic principles as the Koran depicts the arbitrator as a respected member of society. For example, it gives a religious individual the authority to deliver judgments based on any commercial or property disputes (Thomas 2010: 8-11.).

Arbitration awards in countries whose law is based on the Sharia (the code of law adopted from the teaching and guidelines of the Koran) must contain a description of the dispute, the facts as determined under the Sharia, the rationale behind the award with reference to the Sharia, and the decision. The major difficulty is that in such countries it is compulsory for arbitration awards to be reviewed and approved by the courts. ${ }^{7}$ This difficulty has been resolved in several Muslim countries, to some extent, by the ratification of the New York Convention. The latter has limited the grounds on which domestic courts can reject a foreign commercial arbitral award. Nevertheless, the New York Convention permits the rejection of such awards if the enforcement of such award is against that country's public policy.

\section{ARBITRATION LAW IN KUWAIT}

Arbitration, and particularly the ability to refer to arbitration when international commercial disputes arose, became of great importance in Kuwait during the 1940s with the growth of the travel industry within the region. It is noteworthy that the Pleadings Law (Herbert 2009: 3.) (governing arbitration and the way in which commercial parties undertake negotiations) changes with the underlying economic conditions. The growth of the oil industry within Kuwait made it necessary to consider how Kuwait should deal with international challenges. The drive to become more economically efficient and the recognition that international operations were a fundamental part of the economic

${ }^{6}$ Enforcement of Foreign Judgments, Abdullah KH AL-Ayoub \& Associates, Kuwait.

7 Weinberg Wheeler Hudgins Gunn \& Dial, 'Recent Developments in Arbitration Law in the UAE, International Arbitration (2010): 1-20. 
development of the region led to arbitration being formally recognised by the State of Kuwait.

A key part of this analysis of how arbitration is enforced within the State of Kuwait is to identify how Kuwait deals with traditional arbitration. First, the perceived advantages associated with arbitration will offer an explanation, by way of background, as to why certain judicial decisions are enforced in Kuwait and the difficulties that arise in attempting to enforce arbitral judgments within Kuwait for Kuwaiti nationals.

Arbitration broadly falls into one of four categories. First, there is optional arbitration, where the parties may include clauses in their contracts in accordance with which they will submit to arbitration in the event of a dispute. Second, there is institutional arbitration whereby certain businesses, such as the stock market, must be submitted to an institutional arbitration in which the capital markets authority is chiefly responsible and there is no option to opt out. In fact, Kuwaiti arbitration law demands that any arbitration law must be in harmony with public order. In Article $73^{8}$ of the Kuwait legislation, there is provision that conflicting laws (specifically, foreign laws) must not be applied where they violate order or ethics in Kuwait. Third, there is international arbitration. While there is no fundamental distinction between national and international arbitration, international arbitration in Kuwait is generally referred to as any arbitration that falls outside of Kuwait and where Kuwait has agreed to recognise foreign arbitral awards, to a certain extent, thus bringing international arbitral awards within the ambit of Kuwaiti law. Finally, there is judicial arbitration which is undertaken by the Ministry of Justice. This has recently been amended and therefore, as one of the more recent developments in the recognition of arbitral awards in Kuwait, is fundamental to this analysis.

\section{THE ENFORCEMENT OF FOREIGN ARBITRAL AWARDS IN KUWAIT}

In general, the enforcement of foreign arbitral awards in Kuwait is similar to the enforcement of foreign judgments. The enforcement of a foreign arbitral award in Kuwait requires the satisfaction of the five conditions. ${ }^{9}$ First, reciprocity reservation must be considered before any foreign arbitral award is enforced in Kuwait, because some member states only choose to enforce awards from other states that enforce awards formulated in their civil law. Second, due process of service must have been followed to make the arbitral award enforceable. Third, the foreign arbitral award must be the final judgment pronounced by a competent arbitral tribunal in that particular state. Fourth, neither public policy nor morality should be violated by the declaration made in the arbitral award. Finally, the case determined in the award should be capable of being subjected to arbitration, as provided for in the domestic law, that is, Kuwaiti civil law and traditional Sharia law. ${ }^{10}$ There are general guidelines that facilitate the arbitration process in Kuwait. As stipulated in the Pleading Laws, the parties involved in arbitration proceedings are guided by a procedure of either an ad hoc or institutional arbitration rule.

Essentially, Kuwait enforces arbitral awards subject to reciprocity. The arbitration laws in Kuwait are not based on a comprehensive and specific regulation, but rather on the Civil and Commercial Procedure Law. Moreover, it is not dependent on the UNCITRAL Model

\footnotetext{
${ }^{8}$ Court of Cassation Appeal No 39/87 Civil, Hearing 22.

9 Ibid.

10 Ibid.
} 
Law (Herbert 2009: 3); thus the definition of an arbitral award would depend on the choice of law.

In February 1995, Kuwait set up its first arbitration tribunal for civil and commercial issues. This tribunal has been granted exclusive jurisdiction over disputes between private corporate bodies, public authorities, government ministers, and state-owned corporations (Nacimiento 1996: 5-10). The law states that a foreign arbitral award also follows the same system as a domestic arbitral award.

Kuwait enacted the Code of Civil and Commercial Procedure that came into effect in $1980^{11}$ and amendments to other legislations that are crucial for the enforcement of awards. Moreover, being a GCC country, Kuwait has incorporated Sharia law to effect enforcement of foreign arbitral awards.

However, the most significant instrument for Kuwait has been the New York Convention. The New York Convention applies in principle to each and every arbitral award, although certain reservations are permitted to the signatories under Article X. Thus, a Contracting State has the option of recognising and enforcing an arbitral award only if it has been made in another Contracting State. This is the basis of reciprocity. In addition, a Contracting State may declare that it will restrict the application of the Convention to disputes arising from legal relationships that are deemed to be commercial under the laws of the country making such declaration. ${ }^{12}$

Consequently, two important reservations have emerged: the reciprocity reservation, which permits a Contracting State to refuse recognition and enforcement of arbitral awards unless and until the awards have been pronounced in a Contracting State and which were adopted in Kuwait's reservation clause; and the commercial reservations, which allow a Contracting State to restrict the application of the Convention to commercial disputes, as determined by its domestic laws. ${ }^{13}$ These reservations are crucial to Kuwait, as they ensure that it is only obliged to recognise arbitral awards made by Contracting States that recognise arbitral awards from Kuwait.

\section{GROUNDS FOR THE REFUSAL OF ENFORCEMENT OF FOREIGN ARBITRAL AWARDS IN KUWAIT}

The place of countries that declare arbitral awards against Kuwait and do not consider themselves under an obligation to enforce Kuwaiti foreign arbitral awards is not well determined, and parties to such awards may fail to have the awards enforced. There are several grounds that need to be proved by an opposing party in Kuwait. The first is capacity. The incapacity of a party to an arbitration proceeding or an arbitration agreement must be determined by a competent arbitral tribunal. Second, the principles of natural justice must have been upheld, or this can be a ground for not enforcing the arbitral award. Third, there must have been a fair hearing and a lack thereof is a ground for refusal of recognition as a principle of natural justice because it prejudices the interests of the parties to the arbitration agreement. Fourth, where the arbitrator exceeded his powers in making the arbitration award or the arbitration tribunal had no jurisdiction to determine the dispute, then the

11 Law No. 38/1980 (4 January 1980).

12 Ibid. 616.

13 Law No. 38/1980 (4 January 1980). 
Kuwait court cannot enforce such an agreement. Last, adverse procedural irregularities may make the arbitral award wholly unenforceable by any court of competent jurisdiction. ${ }^{14}$

There are additional grounds capable of giving rise to refusal of recognition and enforcement of a foreign arbitral award: where any issue or subject matter submitted to arbitration was not capable of being subjected to arbitration; where the subject matter of the dispute was incapable of being resolved by arbitration, as per the law of that country; and where the public policy of that country would be violated if the foreign arbitral award was granted recognition and enforcement. ${ }^{15}$ Disputing countries have, on several occasions, chosen to use arbitration as the best way to solve their dispute, based on the fact that it is consensual, private, and reasonably effective compared to a court process. The place of arbitration is left to the parties to elect (Geoffrey 1989: 586-596) and this, in some jurisdictions, can be a ground for setting aside an arbitral award (Collier-Lowe 2005: 565569). The place of arbitration must be in a neutral location and should, as far as possible, be unconnected to either of the disputing countries. In addition, the place of arbitration should be equally convenient in terms of access for such countries. Moreover, the place of arbitration should provide the necessary facilities for hearings and meetings required in a dispute between countries (Collier-Lowe 2005).

\section{CONCLUSION}

The main focus of this article was on the extent to which foreign arbitral awards are enforced in Kuwait with various notable exemptions in terms of recognition and enforceability. As an Islamic nation, the legislation of Kuwait is still subject to Islamic laws. Whereas Kuwait has developed legislation to a considerable extent, its Code of Civil and Commercial Procedure is nevertheless based on the Islamic Sharia law. Consequently, the Sharia will have an influence even on international arbitration. This is potentially disadvantageous to businesses from non-Islamic nations.

Nevertheless, Kuwait has consistently honoured its international treaty commitments. To this end, it has emphasised its intention to attach greater importance to such commitments than to its domestic laws. Notwithstanding such intention, when it comes to enforcing foreign arbitral awards, Kuwait can and does protect domestic interests, when such protection favours public policy (Collier-Lowe 2005: 565-569), by virtue of the Kuwaiti Code of Civil and Commercial Procedure.

There are several international laws that govern arbitration in Kuwait, the main one being the New York Convention, which came into effect in Kuwait on 27 July $1978^{16}$ and has been incorporated into domestic law. Additionally, a basis for the recognition and enforcement of arbitral awards is set out in the Code of Civil and Commercial Procedure and other laws, relevant in providing the procedural law as well as the substantive laws that govern the recognition and enforcement of foreign arbitral awards in Kuwait (El-Ahdab, 2011: 60-74). International law principles and treaties are therefore instrumental in the way in which Kuwait arbitration awards are enforced and recognised.

However, the Convention provisions were not adopted wholly; Kuwait held a reservation under Article I(3) of the New York Convention, with no reservation under those

14 Ibid.

15 Ibid.

16 Decree No. 10 of 1978. 
that govern arbitration agreements that involves commercial transactions (FouchardGaillard-Goldman-Savage 1999: 150). Of relevance in the recognition and enforcement of foreign arbitral awards in Kuwait are the grounds permitting the denial of recognition and enforcement. The main ground is that of public policy - that is, if the arbitral award fails to meet the threshold set out in the New York Convention or in the Sharia laws, then it cannot be recognised (Kronke-Nacimento-Otto 2009: 365). Other grounds include the arbitrability of the arbitration dispute. The foreign arbitration proceedings should have been commenced at the earliest time ${ }^{17}$ and in the relevant court. As such, Kuwait recognises and enforces foreign arbitral awards in certain circumstances. However, the Kuwaiti courts are empowered to reject a foreign arbitral award, and such refusal will be on the grounds of lack of reciprocity and public policy.

One key element in ensuring the enforcement of arbitral awards across Kuwait is Kuwait's willingness to become part of an international community in terms of trade, and this requires the Kuwait government to put in place statutory provisions to provide the certainty and finality of arbitral awards, whether they are national or international in nature. It is this continuous desire to harmonise and to become part of the international community that will ultimately lead to greater certainty in the area of the enforcement of arbitral awards.

\section{REFERENCES}

Collier, J.-Lowe, V. (2005): Dispute Settlement in the UN Convention on the Law of the Sea. Cambridge: Cambridge University Press, 565-569.

El-Ahdab, J. (2011): Arbitration with the Arab Countries (3rd edition, Arbitration Center). Kluwer Law International, 60-74.

Fouchard, P.-Gaillard, E.-Goldman, B.-Savage, J. (1999): Goldman on International Commercial Arbitration. Kluwer Law International, 150.

Geoffrey, P. (1989): Settlement of International Disputes: The "Rainbow Warrior" Affair. Commonwealth Law Bulletin: 586-596.

Herbert, S. (2009): Country Factsheet (2nd edition). Dlaiss Lutz and Stibbe, 3.

Kronke, H.-Nacimento, P.-Otto, D. (2009): Recognition and Enforcement of Foreign Arbitral Awards: A Global Commentary on the New York Convention. Kluwer Law International, 365.

Nacimiento, P. (1996): New Law on Civil and Commercial Arbitration. International Commercial Litigation 46: 5-10.

Ragib, W. (1993): Hal Altahkeem Nao'min Alqada? (Is Arbitration a Type of Litigation?) University of Kuwait Law Journal 17 (1): 131-172.

Rothwell, D.-Kaye, S.-Akhatkavari, A.-Davis, R. (2011): International Law: Cases and Materials with Australian Perspectives. Melbourne: Cambridge University Press.

Thomas, K. (2010): Arbitrating Disputes with Middle Eastern Entities. International Law News 39 (2): $8-11$.

17 Article 199 of the Kuwaiti Code of Civil and Criminal Procedure 1980. 